\title{
From Rhetoric to Psychology: the Metamorphosis of the Sublime in Eighteenth-Century British Literary Aesthetics (1700-1740)
}

\author{
ZolTÁn CORA
}

In the first half of the eighteenth century the notion of the sublime was becoming increasingly heterogeneous. It can be explained, as I have recently argued, by an intensifying psychologizing tendency driven by a growing sensitivity in aesthetic perceptions (Cora 2014, 2016). In this paper I intend to further examine the diversification of the concept through looking at the eighteenth-century British reception of Longinus' On Great Writing (On the Sublime), an open text continuously read and reread by British authors, thus tracing the genealogy of the concept from Alexander Pope to John Baillie. Samuel Johnson's magnum opus, A Dictionary of the English Language (1755) serves as a starting point for my inquiry, as it sums up all the major features associated with sublimity in the examined period. When defining the sublime as "the grand or lofty style," Johnson cites Pope's praise of Longinus, quotes Addison and identifies John Milton's work as the best English example of sublime poetry (Wood 195). Johnson's entry on the sublime also draws attention to the fact that not only did the concept undergo a considerable alteration, but it also became widely known by the end of the examined period.

\section{Alexander Pope and the Longinian Tradition of the Sublime}

Gaining considerable plaudits in a relatively short period, Alexander Pope, the 'national critic' and the author of An Essay on Criticism (1711) became an arbiter elegantiae besides Addison and Shaftesbury in the early eighteenth century. Samuel Johnson praises Pope's style for "exhibit[ing] every mode of excellence that can embellish or dignify composition-selection of matter, novelty of arrangement, justness of precept, splendour of illustration, and propriety of digression" (qtd. in Fairer 25). In relation to the Essay, Johnson primarily focuses on Pope's congeniality and the sublimity of his style, the latter in line with Pope's own praise of Longinus. Interpreting Pope's thought within the wider context of literary taste, Johnson evaluates stylistic merits simultaneously with their propriety and rationality, justifiably, as in Pope's work the great thought of Longinus, which inspires the sublime, also becomes coupled with Wit on the wings of Pegasus: 
True Ease in Writing comes from Art, not Chance,

As those move easiest who have learn'd to dance,

'Tis not enough no harshness gives Offence,

The Sound must seem an Eccho to the Sense.

Soft is the Strain when Zephyr gently blows,

And the smooth Stream in smoother Numbers flows;

But when loud urges lash the sounding Shore,

The hoarse, rough Verse shou'd like the Torrent roar.

(Essay 362-369)

Within Pope's system of the ethics and didactics of taste, swiftly and elegantly moving sublimity is to be joined with Sweetness and Light (11-16), Candor and Truth (562-563), as well as with Ease (362). In order to highlight the edifying qualities a good critic ought to follow and fulfill if he wishes to achieve sublimity, Pope also lists the opposites of these qualities: meanness and witlessness (36-41); lack of independence, avarice, the platitudinous and the untrue (566-583). What is more, he often plays with light, if he discusses the clear, grand and sublime style as well as criticism, and thus represents the requisites of clarity metaphorically, too:

But true Expression, like the' unchanging Sun,

Clears and improves whate'er it shines upon,

It gilds all Objects, but it alters none. (Essay 315-317)

Pope is less benevolent with the 'lowlanders of Parnassus', when he further demonstrates the relevance of this view in his Peri Bathous (On the Profound). ${ }^{1}$ He defends the classical grounds of the sublime by ironically instructing the reader in how to reach perfectly low expressions, literary depths and vacuity of sense. In this way Pope renders an inverse reading of the sublime: by a pendant-like logic of showing every stylistic and rhetoric aspect of the opposition between the Sublime and the Profound. If aesthetic perfection is an art, then bathos, the lowest possible thought and expression is also an art form.

I doubt not but the reader [...] begins to be convinced of the truth of our assertion, that the Bathos is an art; and that the genius of no mortal whatever, following the mere ideas of nature, and unassisted with an habitual, nay laborious peculiarity of thinking, could arrive at images so wonderfully low and unaccountable. (Pope 2008, 205)

Peri Bathous: or, Martinus Scriblerus, his Treatise of the Art of Sinking in Poetry. Published on 8 March 1728 in the third volume of Pope-Swift Miscellanies. 
In his quest for achieving refined taste, writing a parody on the Peri Hypsous (On the Sublime) aimed to defoil the "works of the unlearned" (Rogers 2008, 630-631). Pope creates direct correspondence between himself and Longinus, "the secretary of the renowned Zenobia", even in the mock-praise of the 'profound', the 'highest' cannot stand without the 'lowest' (Pope 2008, 196). In order to demonstrate and prove this point, Pope explores all the figures and tropes to bring forth the bathos in an admirably satiric manner, using puns on adversaries to advantage (Blackmore, Curll, Cibber, Theobald, Dennis, etc.). In this aspect, it is in direct relation to The Dunciad as well. ${ }^{2}$ The most essential features of the bathos are affectation, pertness, needless complexity, confusion and obfuscation in contrast to the ideals of simplicity, decorum, point and directness (Pope 2008, 206-230; Rogers 2008, 631-632).

In addition to this, Pope's views on the sublime-just like those of Addison and Shaftesbury - can only be understood in the wider context of his thoughts on literary taste, laid out in his Essay imitating Horace's Ars poetica. ${ }^{3}$ Aesthetic questions in general were discussed in relation to the question of taste because art was seen to serve didactic and moral purposes. Pope's judgements of taste revolve around two key concepts: manners and the ability of distinguishing between the beautiful and the ugly. "Manners" are the skill of distinguishing between good and bad, which ideally aims to create a humorous, tolerant and perceptive rapport:

Be niggards of advice on no pretence;

For the worst avarice is that of sense.

With mean complaisance ne'er betray your trust,

Nor be so civil as to prove unjust.

Fear not the anger of the wise to raise;

Those best can bear reproof who merit praise. (Essay 578-583)

In this respect, Pope adhered to the intentions of the Martinus Scriblerus Club. In the congenial wording of Pat Rogers, the club "perfected a kind of high-spirited spoofing, involving parody, intellectual practical jokes, and an onslaught upon all things pedantic" (Rogers, 2008, xiv). All of the Scriblerus Club's members took pains to establish an educated public discourse, in which artistic performances

2 For examples of parallels with The Dunciad, see Rogers (2008, 631-632). The most important authors overlapping in the two works are Addison, Aphra Behn, Cleveland, Dennis, Eusden, Nathaniel Lee, Ambrose Philips, Quarles, Steele, Theobald and Tickell.

3 It is John Dennis whom Pope regarded as a bad critic, who provoked Pope into writing a theory of art and literary criticism in a poetic form (Rogers, 1975, 29).

4 On the forerunners of Pope with regard to this, see Fairer (34-36).

5 All line references are taken from a 1965 edition of Pope's Essay. 
could be judged and assessed by a refined taste (Cora, "Pope" 18-19). In addition to manners, the other source of judgements of taste was the ability to distinguish between the beautiful and the ugly, which also helps the critic to compare works of art on the basis of their cultural contexts and artistic intentions. According to Pope, one has to strive for universality when forming judgements of taste so that Truth (in the sense of natural law) could be revealed. The uncovering of truth, however, is a personal, human as well as a moral obligation, and not an abstraction or metaphysical finiteness:

Learn then what Morals Criticks ought to show,

For 'tis but half a Judge's Task, to Know.

'tis not enough, Taste, Judgement, Learning, join;

In all you speak, let Truth and Candor shine:

That not alone what to your Sense is due,

All may allow; but seek your Friendship too. (Essay 560-565)

Furthermore, in order to have a universal validity, judgements have to be based upon sense and naturalness. According to Pope, sense is a moderate form of understanding, which also has decorum:

'Tis hard to say, if greater Want of Skill

Appear in Writing or in Judging ill;

But, of the two, less dang'rous is th' Offence,

To tire our Patience, than mis-lead our Sense:

Some few in that, but Numbers err in this,

Ten Censure wrong for one who Writes amiss;

A Fool might once himself alone expose,

Now One in Verse makes many more in Prose. (Essay 1-7)

Ratio is opposed to the vacuity of mind and the lack of erudition: it has to harmonize with artistic expression and is part of critical intelligence, but at the same time it is poignant and sensible:

Pride, where Wit fails, steps in to our Defence, And fills up all the mighty Void of Sense!

[...]

Some dryly plain, without Invention's Aid, Write dull Receits, how Poems may be made:

These leave the Sense, their Learning to display,

And those explain the Meaning quite away. (Essay 209-210, 114-117) 
If taste is refined in due accordance with the principles of the art of poetics, while precision and decorum with the help of common Sense, as both are cognitive faculties, then, as Andrew Sanders has argued, style impresses with the sensation of naturalness (287-89).

The essence of nature is invisible, can only be witnessed in its manifestations, and it sets limitations to talent within which one's artistic lore can be perfected by art. Pope interprets Nature as divine force (1. 68-73), and as the cosmos itself, the order, symmetry and harmony of which the work of art must imitate and reflect (l. 74-87). ${ }^{6}$ By its internal, lively essence, Nature is the opposite of artificiality and at the same time, the source of inspiration, while art provides those forms which this inspiration could infuse and through which it could create beauty:

In Wit, as Nature, what affects our Hearts

Is not th' Exactness of peculiar Parts;

'Tis not a Lip, or Eye, we Beauty call,

But the joint Force and full Result of all. (243-246)

Even if the Essay is the "handbook of Augustan orthodoxy" (Bronson 18), Pope, in a timely manner, corrects the seemingly rigid notions attributed to nature by balancing between great wits and gentler forms of Nature. As H. B. Bronson has noted, Pope's "pathetic tenderness" makes it possible that extravagancies and lovely descriptions of a gentler Nature appear in "Windsor Forest" (1704, 18-21). Besides a nuanced depiction of nature, it can also be argued, however, that Pope develops his ideas on sublimity in the early eighteenth-century amidst heterogeneous interpretations of the concept ranging from its definition in terms of a crisp and grand style to its association with wild nature's affective force of awe and terror. It is my contention that Pope represents the peripatetic tradition within these heterogeneous conceptualizations. Artistic intention, naturalness and creative force are therefore sine qua nons; however, similarly to Horace, Pope allows a genius minor mistakes, thus making ground for poetic licence (licentia):

If, where the Rules not far enough extend,

(Since Rules where made but to promote their End)

Some Lucky Licence answers to the full

Th' Intent propos'd that Licence is a Rule.

Thus Pegasus, a nearer way to take,

May boldly deviate from the common Track.

6 For further details on the complexity of the concept of nature in the eighteenth century, see Lovejoy (69-77). 
Great Wits sometimes may gloriously offend, And rise to Faults true Criticks dare not mend; From vulgar Bounds with brave Disorder part, And snatch a Grace beyond the Reach of Art, Which, without passing thro' the Judgment, gains

The Heart, and all its End at once attains. (146-155)

The poet transforms the negative downward pressure of rules into positive compression. His concentrated energy oscillates between the poles of contraction and release. Hence, sublimity is manifested in the grand style, and only poetic Wit is able to reach true Sublime, the par excellence examples of which the author finds in the works of masters of classical antiquity with their perceived universal validity. Pope elaborates further on the idea of universal values in a later work delineating his moral philosophy, An Essay on Man (1733-1734), in which Man is represented as part of the all-pervasive harmony of the order of nature, which binds every creature according to the scheme of the "great chain of Being" with God at its ultimate source (Epistle II, Argument 1-15, see Hollander and Kermode 1973).

Consequently, in almost all cases, these peripatetic and formalistic elements underpinning the genus grande originate from the Longinian philological tradition with its extensive allusions. ${ }^{7}$ Furthermore, Pope explicitly praises Longinus:

Thee, bold Longinus! all the Nine inspire,

And bless, their Critick with a Poet's Fire

An ardent Judge, who Zealous in his Trust,

With Warmth gives Sentence, yet is always Just;

Whose own Example strengthens all his Laws,

And Is himself that great Sublime he draws. (675-680)

Longinus' praise brings to an end a beautiful series of enkomions, praising Horace (653-664), Dionysius Halicarnasseus (665-666), Petronius (667-680), and Quintilianus (669-674), which Pope rounds off by highlighting his own critical standpoint (719-746). In sum, Pope interprets the sublime as a rhetorical category relying on erudition and a refined taste; on the basic rhetorical tenets of the peripatetic tradition of the sublime since Aristotle and Theophrastus. While most of his contemporaries tended to reconceptualize the sublime in empiricist and psychological terms, Pope advocated a strand of neoclassical literary aesthetics, which springs from a wide spectrum of sensibility, and thus conjoins heterogeneous interpretations of sublimity. Pope provides a par excellence example of what he

For further details see Cora 2014. 
meant by the genus sublime, positioning himself as the spearhead of this tradition, inspiring others in his wake.

\section{The Uncommon, the Beautiful, and the Great in the Journals and Beyond}

Journals were one of the crucial cultural forums where the eighteenth-century transformation of the concept of the sublime took place. As is widely known, throughout the eighteenth century clubs and coffee-houses, sites of simultaneous consumption of beverages and journals, played an important role in the formation and refinement of taste, and anticipated the nineteenth-century flourishing of the British press. Those who published in journals, like The Tatler and The Spectator, wished to present their literary, philosophical and aesthetic ideas to the members and visitors of diverse clubs.

It was The Spectator (launched by Richard Steele and John Addison in 1711) that made the greatest breakthrough in the "market of tastes," but minor journals and periodicals were also engaged in shaping public taste and discussing, among numerous other fashionable topics, Longinus and the sublime. In line with literary and critical works, these newspapers use the notion of the sublime in an astounding variety. In one of the articles of The Free Thinker, sublimity is described in terms of distraction, separating the human being from everyday, practical things, as is explained by the editor, Ambrose Phillips:

It is generally thought, the student is so deeply immerst in Contemplation on the Philosophy and Transactions of Former Ages, that he can give no Attention to the Affairs of the Present; or, that he is so intent upon General and Sublime Truths, that his Observation stoops not to the minute and trifling Occurrences of Life: And that, notwithstanding the comprehensive Rules of Wisdom he may have formed in Theory, he has not the Skill and Dexterity to apply those Maxims to the particular Circumstances of Action, in which he may be engaged. (The Free Thinker, No. 89. Monday, January 26, 1718) (Wood 138). ${ }^{8}$

Yet another newspaper, The Plain Dealer, presents the sublime variably as "the greatest," as well as in the original Longinian sense of simplicity, the greatness of an idea and moral sentiment. The editors, Aaron Hill and William Bond, discuss the question of sublimity in the following way:

8 If otherwise not indicated, some parts of the quotations are italicised by the author in order to highlight the relevant sections. 
But, though this venerable, undress'd Nature, is seldom to be met with now, and has, indeed, been lost among us, for above a Century, it was so frequent Two or Three hundred Years ago, that their lowest Class of Poets, and the Composers of our good Old Ballads, have left us some of the noblest Examples of the Sublime, in its most striking Energy. [...] Among the Beauties of Magnanimity, there is none, of a nobler Quality, than the Power of forgiving Injuries. - - It throws a Majesty over the Mind, and illustrates the Person, with an Air of Sweetness, and Serenity. - - We ought the more to admire it, since, where-ever it is found, it is in Company with the Sublimest Virtues: There not being Room for it, in a narrow, vulgar, Soul; because, overfll'd with Little Sentiments, such as have their Rise, and Revolution, within the Circle of Self-Interest (The Plain Dealer No. 36. Friday, July 24, 1724; No. 72. Friday, November 27, 1724; qtd. in Wood 141, 145).

Most importantly, however, the sublime was also discussed by Mr. Spectatorthe fictional protagonist of The Spectator Club, founded by Steele and Addison in 1711 - a key figure in forming public taste in London, which became the emporium of the contemporary world (Sanders 296-97). Mr. Spectator was a man of broad education; he was well-travelled and politically alert. Samuel Johnson later pointed out that The Spectator exercised enormous influence on contemporary readers. Its sizeable reading public enabled the authors to induce balanced norms of taste in mundane as well as in literary communication (Sanders 295). Dr. Johnson went as far as describing Addison as England's Petronius:

The Tatler and Spectator had the same tendency; they were published at a time when two parties, loud, restless, and violent, each with plausible declarations, and each perhaps without any distinct terminations of its views, were agitating the nation; to minds heated with political contest they supplied cooler and more inoffensive reflections; and it is said by Addison, in a subsequent work, that they had a perceptible influence upon the conversation of that time [...] they superadded literature and criticism, and sometimes towered far above their predecessors; and taught, with great justness of argument and dignity of language, the most important duties and sublime truths. All these topics were happily varied with elegant fictions and refined allegories, and illuminated with different changes of style and felicities of invention (Johnson 205).

In Addison's view, taste is "that Faculty of the Soul, which discerns the Beauties of an Author with Pleasure, and the Imperfections with Dislike" (The Spectator No. 409). ${ }^{9}$ For Addison fine taste is the edifying understanding of works of art, a refined

9 All references to The Spectator are taken from a 1982 edition. 
skill of making aesthetic distinctions and the recognition of beauty (Sanders 295). The 'critic' has to be able to judge the individual stylistic traits of an author and those "Specifick Qualities" which are only characteristic of the author: "For there is much difference in apprehending a Thought cloathed in Cicero's Language, and that of a common Author, as in seeing an Object by the Light of a Taper, or by the Light of the Sun" (The Spectator No. 409.). In line with Longinus, Addison originates judgement of taste and literary taste from various sources. First of all, good taste is an inborn talent. Secondly, it is a knowledge gained by perusing works of "Polite Authors," and third, it is a conversation with a "Polite Genius." The fourth source, astonishment, is perhaps the most important of all, because this psychological state is conventionally associated with sublimity:

Thus altho' in Poetry it be absolutely necessary that the Unities of Time, Place and Action, with other Points of the same Nature, should be thoroughly explained and understood: there is still something more essential to the Art, something that elevates and astonishes the Fancy, and gives a Greatness of Mind to the Reader, which few of the Criticks besides Longinus have considered (The Spectator No. 409.).

Addison argues that, among the five human senses, sight is "the most perfect and most delightful [...] [since it] furnishes the Imagination with its Ideas" (The Spectator No. 411.). So, when perceiving reality, images fill our Fancy which "arises from visible Objects, either when we have them actually in our view, or when we call up their Ideas into our Minds by Paintings, Statues, Descriptions, or any the like Occasion" (The Spectator No. 411). However, sight is the source of not only the instinctual ability to form images, but it is also the basis of an active and wilful characteristic of the human being, namely, Imagination. The creative resource of Imagination enables human beings to bring forth new and as yet nonexistent combination of images that can be more sophisticated and beautiful than the creations of nature.

Addison distinguishes the "Pleasures of Imagination" from the "Pleasures of Sense and Understanding." The former always acts upon our emotions and fancy, while the latter on our intellect and mind. If Imagination is guided by refined taste, it may expand human sensation, and it might disinterestedly attract the observer to beauty and thus fill him/her with joy:

It is but opening the Eye, and the Scene enters. The Colours paint themselves on the Fancy, with very little Attention of Thought or Application of Mind in the Beholder. We are struck, we know not how, with the symmetry of any thing we see, and immediately assent to the Beauty of an Object, without enquiring into the particular Causes and Occasions of it. A man of a Polite Imagination is led 
into a great many Pleasures, that the Vulgar are not capable of receiving. He can converse with a Picture, and find an agreeable Companion in a Statue. He meets with a secret Refreshment in a Description, and often feels a greater Satisfaction in the Prospect of Fields and Meadows, than another does in the Possession. It gives him, indeed, a kind of Property in every thing, he sees, and makes the most rude uncultivated Parts of Nature administer to his Pleasures (The Spectator No. 411.).

The so-called 'primary qualities' inspire Imagination the most: the Great (conventionally associated with the sublime), the Uncommon, and the Beautiful. By Great, Addison understands the "Largeness of a whole View":

Our Imagination loves to be filled with an Object, or to grasp at any thing that is too big for its Capacity [...] We are flung into a pleasing Astonishment at such unbounded Views, and feel a delightful Stillness and Amazement in the Soul at that Apprehension of them [...] a spacious Horizon is an Image of Liberty, where the Eye has Room to range abroad, to expatiate at large on the Immensity of its Views, and to lose it self amidst the Variety of Objects that offer themselves to its Observation (The Spectator No. 412.).

Infinity and greatness draw our attention instinctually, and if this free sensation is accompanied by the Uncommon and the Beautiful, then the pleasure felt when sensing these is all the greater. The Uncommon is usually variety and refreshment, which ensures that we receive the "Imperfections of Nature" with joy. The Beautiful, in turn, is the combination of "Satisfaction," "Complacency," and "inward Joy" in our Fancy, which "immediately diffuses a secret Satisfaction and Complacency through the Imagination, and gives a Finishing to any thing that is Great or Uncommon" (The Spectator No. 412.).

When discussing the notion of the Beautiful, Addison partly draws upon Anthony Ashley Cooper's (the third Earl of Shaftesbury) ideas on the Beautiful. Lord Shaftesbury, who worked out his theory of the Beautiful on a Lockean basis, embedded his theory of the Beautiful in a wider concept of taste (Monk 59; Townsend 205-13). Shaftesbury thinks that taste is the result of value judgements. He claims that the unreflected and direct sensual information gained by perception through the senses is misleading, because they are not filtered and structured by morally acceptable value judgements. Therefore, all value judgements aim at correcting and perfecting these pieces of perceptual information in order to provide for our taste by simultaneously taking beauty, virtue and other moral and aesthetic notions into account, as 'uncontrollable Fancy' necessarily leads to morally inadmissible and unedifying results. Thus, fine taste is built upon principles of moral philosophy, and thereby, it can be learnt, brought forth and developed (Townsend 209-10). 
In this respect, Shaftesbury's theory is similar to that of Alexander Pope, as it locates the sources of taste and aesthetic sensation in the realms of formalistic and peripatetic traditions.

However, in order to better understand how aesthetic notions are linked to taste, it is also worth exploring the relationship of beauty and sublimity to taste. In Shaftesbury's system of aesthetics two kinds of beautiful are possible: the pleasures gained from the beauty of sensation and of rational reflection. He examines the former in The Moralists (1709), and the latter in his Reflections (1711). Shaftesbury claims that "disinterestedness" can be realized in aesthetics, a clear indicator that aesthetics as a system of thought as well as a discipline was embedded in the rational philosophical milieu of the eighteenth century. Contrary to other authors, including Thomas Hobbes, Shaftesbury believed in disinterested value judgements that are grounded in solid morality (Townsend 211). ${ }^{10}$

Shaftesbury's views on aesthetics neatly conjoin the Neoplatonic thought of Plotinos and Lockean empiricism. He draws upon Neoplatonism in proposing that discovering and acting upon Beauty, which, in a pre-existent form was implanted in human beings and nature through the emanation of the Superior Being, necessarily serves the perfection of the morals and the taste of the individual (Townsend 208). Consequently, the basis of aesthetics can only be the true and the allegorical. Shaftesbury's empiricism, in turn, is attested by his claim that one has to find and assort the empirical forms that feed aesthetic sensation in this earthly realm in order to perfect one's taste. One needs to mend these forms, however, in compliance with inner Beauty, as he suggests in The Moralists:

No sooner are actions viewed, no sooner the human affections and passions discerned (and they are most of them as soon discerned as felt) than straight an inward eye distinguishes, and sees the fair and shapely, the amiable and admirable, apart from the deformed, the foul, the odious, or the despicable (326). ${ }^{11}$

This idea shows an affinity not only with Addison, but also with Giovanni Pietro Bellori's ideas (L'Idea del Pittore, dello Scultore, e dell'Architetto, 1664), with whose work both Shaftesbury and Addison were familiar. According to Bellori, the artist carries within himself the idea of 'undisturbed' Beauty, in relation to which natural forms could be perfected in artistic representations. In other words, the artist has to draw his examples from sensual perception, but unite them with inner Beauty,

\footnotetext{
10 The idea of "disinterestedness" was developed into a complex philosophical and aesthetic concept by Immanuel Kant when discussing the notion of pure beauty (1790).

11 The wording of Shaftesbury is very similar to Addison's rhetoric. See Shaftesbury (326).
} 
this way creating more sophisticated and sublime artistic forms than what could be found in nature (Panofsky 59-60). ${ }^{12}$ Bellori's principle provided the basis for subsequent perfectionist and idealist aesthetics. It is my contention, however, that in Shaftesbury's and Addison's view, the imagination, which draws upon another source of beauty, sensual pleasure, neatly complements this classicist aesthetic paradigm in early eighteenth-century British literary criticism.

In line with Bellori and Shaftesbury, according to Addison, the essence of aesthetic joy and sublimity cannot be entirely known, since it originates from God. This is suggested by a line from Ovid quoted in The Spectator by Addison: "Causa latet, vis est notissima" [The cause is hidden, but the result is well-known] (Metamorphoses, 4, 287; The Spectator No. 413.). Such a view is consonant with the Aristotelian causa finalis, namely that one can only understand the origin and nature of a phenomenon by studying the purpose for which it was conceived (Bolonyai 37-53). ${ }^{13}$ The sensation of joy is brought forward by the imagination, which is seen by Addison as a gift from God. This idea, however, was not unique to Addison, as it was a contemporary understanding that God implanted in humans the desire to search for the infinite, the uncommon and the beautiful because he wanted us to share the joys of creation (Sander 296; Pappas 17-27). In addition to the Uncommon and the Beautiful, the Great (the Sublime) is God's manifestation in nature; therefore, it is infinite and cannot be described either in space or time. Addison argues that our wonder originates from perceiving these qualities of greatness (The Spectator No. 412.).

Nature is more sublime, greater and more majestic than the arts, yet, one can gain double joy from the arts, since one can simultaneously admire the original and the imitated Beauty. ${ }^{14}$ The idea of double aesthetic joy through mimesis provides the basis for the so-called 'Secondary Pleasures of Imagination' which are produced by the operation of imagination and analogy (especially a comparison between the original and the represented). Addison argues that this simultaneous operation of imagination and analogy explains why in both poetry and prose one can depict something more precisely, sharply or beautifully than observing the same in nature:

12 See Bellori's comments in detail: "alla cui immaginata forma le cose che cadono sotta la vista [...] originata della natura supera l'origine e fassi l'originale dell'arte” (Panofsky 59-60).

13 Aristotle Physics II 3 and Metaphysics V 2.; for the relationship of sublimity and the Aristotelian causa finalis, see Bolonyai (37-53).

14 The theory of mimesis was widely accepted in the eighteenth century. Both the neo-classicists and the pre-romantics subscribed to it, even though they arrived at different conclusions. See, for example Friedrich Schlegel's note: “die romantische Poesie wie eine progressive Universal Poesie” (qtd. in Lovejoy 69-77). 
the Poet seems to get the better of Nature; he takes, indeed, the Landskip after her, but gives it more vigorous Touches, heightens its Beauty, and so enlivens the whole Piece, that the Images which flow from the Objects themselves appear weak and faint in Comparison of those that come from the Expressions (The Spectator No. 416.).

Therefore, Addison's sublimity has two preconditions: the ingenious artist/ poet and vast, awe-inspiring nature. Addison systematically applied the notion of the sublime to nature and the huge reading public of The Spectator considerably contributed to the dissemination of the notion of the sublime in such terms (Monk 58-59). However, the concept of the 'sublime' never completely shed the merits and faults of its rhetorical origins, and with the implication of the idea of the genius, it conformed to neo-classicist conventions. Primary pleasures (Great, Uncommon, Beautiful) are united in the sublime, which, according to Addison, is best exemplified by John Milton's poetry, as it combines the greatness of Homer, the elegant style of Virgil and the variety of Ovid, even if, Addison adds, Homer, Virgil and Ovid outdid Milton in the respective above mentioned qualities: "I must also observe with Longinus that the Productions of a great Genius, with many Lapses and inadvertencies, are infinitely preferable to the Works of an inferior Kind of Author, which are scrupulously exact and conformable to all the Rules of correct Writing" (The Spectator No. 291.). ${ }^{15}$

In the wake of Addison, later authors tended to regard Milton, next to Shakespeare, as the first representatives of English sublimity, in spite of the fact that the rhetorical interpretation of the sublime could hardly take Shakespeare's and Milton's works into consideration due to their blank verse (Monk 56). ${ }^{16}$ Indeed, the sublimity of Shakespeare-denounced by numerous men of letters in the eighteenth and nineteenth centuries for violating the neoclassical convention of decorum - was not conceived in rhetorical terms. It was rather identified with the loftiness of his thought and emotions with reference to the ninth chapter of Longinus' text. An excellent example of this kind of interpretation is John Upton's 1746 study, Critical Observation on Shakespeare, By John Upton, Prebendary of Rochester (Wood 133-37). In contrast to this, however, in his Explanatory notes and remarks on Milton's Paradise Lost (1734), Jonathan Richardson discusses John Milton's poetry in terms of the whole Longinian spectrum of the sublime, even though he underlines the predominance of divine inspiration and revelation in the case of Milton's sublime. John Douglas in Milton vindicated from the charge of

15 See Longinus' On Great Writing, 36.

16 Several quotations are taken from an anthology by Theodore Wood and the seminal work of Samuel Holt Monk. 
plagiarism, brought against him by Mr. Lauder (1751) also refers to Longinus when defending Milton's "mimetic art" against the charges of William Lauder set forth in An essay on Milton's use and imitation of the moderns in his Paradise Lost (1750). Richardson argued that imitation (mimesis) could not be considered plagiarism. On the contrary, it is one of the sources of the sublime, since erudition and cultural refinement could be neatly combined with congeniality (Wood 118-19, 129-30).

As it has been pointed out, the idea that in relation to sublimity the human mind could transcend nature in conceiving greatness could already be witnessed at the beginning of the eighteenth century (Monk 17). This idea was neatly linked to the earlier, rhetorical tradition of the sublime through a selective reception of Longinus' work, which opened up the interpretation of the notion of sublimity towards the imagination. Addison gained decisive experiences when ascending the Alps, and the lines in A Letter from Italy describing the Colosseum in Rome also attest to this altering conception of the sublime: "an amphitheater's amazing height, / How fills my eye with terror and delight" (Monk 56). Consequently, Addison finds the sources of the sublime in the spark of genius on the one hand, and in certain natural phenomena on the other: mountains, fast-flowing rivers, oceans, huge valleys, storms, deserts, and so forth. ${ }^{17}$

Addison argues that the human imagination could not fully comprehend these phenomena, as it is "astonished," "amazed," and "awed" by them. Nonetheless, as it is also explained in A Letter from Italy, the human intellect intervenes and elevates the mind to loftiness so that it could become equal with nature's greatness and due to this increase, one could enjoy contented pleasure (Monk 56). In this respect Addison foreshadows the empirical and psychological interpretation of the sublime by Edmund Burke, and its later metaphysical refinement by Immanuel Kant.

Moreover, sublimity is related to immense personal sensations and experience, so, it incites joy if one intuitively 'lives through' the situation of the 'hero,' and the comparison of this experience with one's own real situation yields an opportunity to learn and develop emotionally. In my view, this aspect is very important to understand, and it also partly explains the psychological and affective shift in the interpretation of the sublime in early eighteenth-century literary aesthetics. In this regard, Addison builds upon Aristotle's theory of catharsis, where tragedy arouses terror and pity, and effects catharsis with the emotive purification of these emotions. Thus, the Aristotelian categories of fear, sympathy and absolution are intricately woven into the elevated notion of sublimity:

${ }_{17}$ For similar observations concerning the affective powers of nature in the oeuvre of John Dennis, see Cora 2014. 
There is yet another circumstance which recommends a Description more than all the rest, and that is, if it represents to us such Objects as are apt to raise a secret Ferment in the Mind of the Reader, and to work, with Violence, upon his Passions. For, in this Case, we are at once warmed and enlightened, so that the Pleasure becomes more Universal, and is, several way, qualified to entertain us [...] The two leading passions which the more serious Parts of Poetry endeavour to stir up in us, are Terror and Pity (The Spectator No. 418).

The poet/artist creates the conditions of the sublime with the use of phantasy and fictionality, provided he does not transgress the limits of absurdity (decorum). On the basis of Longinus, Addison developed a psychological answer given to sublimity, also emphasizing the affective power of nature. From a philosophical perspective, however, his view of the sublime remained relatively superficial, especially if compared to Burke's and Kant's complex treatment of the concept.

\section{Affections and Astonishment: From Akenside to Baillie and Johnson}

Addison was not the only one to shift the interpretation of the sublime towards a more empiricist and psychological basis. Mark Akenside's The Pleasures of Imagination (1744) is inspired by Addison's essay, but offers a closer reading of Longinus. The sublime of Akenside is built upon the analogy between the greatness of the mind and natural greatness. Akenside holds the beautiful to be useful, soft and gentle, as it represents the classical (Platonic) unity of goodness and truth, while sublimity pertains to the immortality of the human being, hence it strives for infinity which, at the same time, produces an astonishing effect, as the following quote, haunted by Longinus, illustrates:

Who but rather turns / To heav'n's broad fire his unconstrained view / Than to the glimm'ring of a waxen flame...? [Nobody would turn away from the magnificent sight of the Nile or the Ganges in order to] "[...] mark the windings of a scanty rill / That murmurs at his feet" (The Pleasures of Imagination, 1, 2, 174-176) (qtd. in Monk 71-72). ${ }^{18}$

The passage clearly shows a shift in the interpretation of sublimity towards affective and astonishing characteristics, which were increasingly associated with nature and natural phenomena. Along with the explicit or implicit reflections on

\footnotetext{
18 Akenside refers to Section 4 in Chapter 35 in Longinus' On Great Writing, replacing Longinus' reference to the Danube and the Rhine with a reference to the Ganges.
} 
Longinus' work and the rhetorical sublime, other emerging interpretations of the sublime conceived of it as a mode of sensation and passion. Henry Pemberton, for instance, welds rhetorical and natural sublimity in the notion of the sublime of sensitivity (Observations on poetry, especially the epic: occasioned by the late poem upon Leonidas (1738) (Wood 60). ${ }^{19}$

Most rhetorical works broadened formalistic interpretations of sublimity, shaped by the knacks and rules of French 'rational' classicism. They dwelt upon the sensible aspects of sublimity by highlighting and dissecting its affective nature. Consequently, the discussions of stylistic and rhetorical features were extended to explore the sensual and psychological features of perceiving sublime phenomena as well. Most importantly, in poetics and literary criticism the Beautiful and the Sublime became increasingly separated during the 1730s and 1740s, and Longinus' reception played a crucial role in this process. In his translation of Longinus (1739), William Smith expands the Longinian text with selected excerpts from Milton and Shakespeare; for instance, the storm scene in King Lear as a par excellence example of sublime greatness. He interprets terror as the key factor in sublimity, which underpins the separation of the beautiful and the sublime, since beauty cannot be reconciled with any negative sensation, thus foreshadowing the graveyard poets:

It is not the blue sky, the cheerful sun-shine, or the smiling landskip, that gives us all our pleasure, since we are indebted for no little share of it to the silent night, the distant howling wilderness, the melancholy gnot, the dark wood, and hanging precipice. What is terrible, can be described too well; what is disagreeable should not be described at all, or at least should be strongly shaded. (Smith qtd. in Monk 67)

Similarly to Akenside in his The Pleasures of Imagination, in An Essay on the Sublime (1747) John Baillie also refutes to view sublimity solely from the rhetorical standpoint, as he regards sublime style as an expression of natural sublimity. Consequently, he examines poetic sublime along with the natural sublime, in line with his thoughts on sensation:

But as a Consciousness of her [the soul's] own Vastness is what pleases, so nothing raises this Consciousness but a Vastness in the Objects about which she is employed. For whatever the Essence of the Soul may be, it is the Reflections arising from Sensations only which make [sic] her acquainted with Herself and

\footnotetext{
19 For further examples (for instance, John Lawson: Lectures concerning oratory. Delivered in Trinity College, Dublin (1759); Isaac Hawkings Browne: An Essay on Design and Beauty (1739), see Wood 79-86, 109-12.
} 
know her Faculties. Vast objects occasion vast Sensations, and vast sensations give the Mind a higher Idea of her own Powers - small scenes (except from Association...) have never this Effect; [...] the Soul is never filled by them. (qtd. in Monk 74)

Pointing out that Longinus does not specify the essence of sublimity, Baillie identifies three major sources: (1) Vastness; (2) Uniformity; (3) Novelty (Ashfield and de Bolla 87-100). Uniformity enables human imagination to perceive and systematize visual stimuli, even if it has sensual access to only part of the whole view, hence Baillie attributes a high aesthetic value to uniformity:

For what a different Conception must the Soul have of herself, when with the greatest Facility she can view the greatest Objects, and when with Pain she must hurry from part to part, and with Difficulty acquire even an incomplete View? [...] When an Object is vast, and at the same time uniform, there is [sic] to the Imagination no Limits to its Vastness, and the Mind runs into Infinity, continually creating as it were from the Pattern. (qtd. in Monk 75)

Therefore, for Baillie sublimity is an objective quality, but it involves emotion and is realized through perception. The objective qualities of the sublime generate awe, but they do not move. Similarly to Hume (Neill 246-59), Baillie thinks that the subjective shocking effect of the sublime originates not only from the affective and astonishing power of nature, but also from contemplating exceptional people's acts, characteristics, or, for instance, will, which surpass average people's respective qualities. If this subjective sublimity is aimed at, then heroism, power, the desire for fame, and even a "ruthless conqueror" can be seen as sublime. This idea by Baillie also shows that astonishment and its relation to the effect of sublimity not only appeared more frequently in these discourses but it also encompassed aesthetic features beyond the conventional affective characteristics of natural phenomena. According to Baillie, these two oppositional states, namely the objective and subjective sources of the sublime do "succeed each other by such infinitely quick Vicissitudes, as to appear instantaneous" (qtd. in Monk, 76-82). Unlike earlier neo-classical interpretations that located the origin of Aristotle's tragic paradox (especially in relation to the puzzle of explaining why we enjoy tragedies) in cognition (recognition and learning), Baillie in the eighteenth century and practically all theoreticians of the sublime thereafter identified sensation as its source. By envisioning the sublime as qualitatively determined by sensual associations, Baillie reinterprets the concept in psychological terms.

I bring this investigation to an end by way of returning to Samuel Johnson's magnum opus, A Dictionary of the English Language (1755), demonstrating all the features of the sublime so far discussed. Johnson defines sublimity primarily 
as "the grand and lofty style," noting that the term was originally a Gallicism, but by his time it has become a 'neutral' notion. He first cites Pope's praise of Longinus (An Essay on Criticism, lines 675-680), then quotes Addison to illustrate the astonishing and moving effect of sublimity: "The sublime issues forth from the nobleness of thoughts, the magnificence of the words, or the harmonious and lively turn of the phrase; the per-sublime arises from all three together" (qtd. in Wood 195). He explains the French word, sublimer, as "to raise on high," alluding to John Milton along the way as the most appropriate English literary example of sublimity challenging the maxims of classicist poetry (smoothness, regularity and simplicity): "Milton's distinguishing excellence lies in the sublimity of his thoughts, in the greatness of which he triumphs over all the poets, modern and ancient, Homer only excepted" (qtd. in Wood 195). Milton also represents a shift from stylistic and formalistic approaches to essential and affective ones in relation to sublimity.

\section{Conclusion}

In conclusion, the Longinian sublime began to be transformed and reinterpreted in various fields of British literary aesthetics by the 1730s and 1740s, well before Burke, even though the reputation of Longinus' work remained immaculate. The texts analyzed show a motley picture of how literary sublimity was perceived, yet certain tendencies are apparent. Almost all the sources define the sublimeimplicitly or explicitly_against the beautiful, situating the sublime in the domain of the sensual and psychological. Stylistic and rhetorical considerations, in other words, the formalistic aesthetic grounds of sublimity, expression, are gradually rendered secondary. Instead, the effect on the viewer, the impression comes to occupy the centre stage of critical attention. This development is encapsulated in Samuel Johnson's dictionary, which, in my view, also highlights the major reasons why the most striking form of the representation of sublimity, the natural sublime advances to the forefront of aesthetic topica maiora.

\section{Works Cited}

Ashfield, Andrew, and Peter de Bolla, eds. 1998. The sublime. A reader in British eighteenth-century aesthetic theory. Cambridge: Cambridge University Press. 
Bolonyai Gábor. 2007. "Fenség és nézőpont." Antik Tanulmányok, 54(1): 37-53.

Bronson, B. H. 1967. "When Was Neoclassicism." In: Howard Anderson and John S. Shea, eds. Studies in Criticism and Aesthetics, 1660-1800. Essays in Honor of Samuel Holt Monk. Minneapolis: University of Minnesota Press, 13-35.

Burke, Edmund. 2008. A Philosophical Enquiry into the Origin of our Ideas of the Sublime and Beautiful. 1757. Ed. Adam Phillips. Oxford: Oxford University Press.

Cora, Zoltán. 2014. "From the Rhetoric of Longinus to the Poetics of John Dennis. The Role of Terror in the Theories of the Sublime in the $18^{\text {th }}$ Century." In: György Fogarasi, Zoltán Cora, and Ervin Török, eds. Terror(ism) and Aesthetics. Et al. - Critical Theory Online. Szeged: Department of Comparative Literature. Available at URL:http://etal.hu/en/archive/terrorism-and-aesthetics-2015/corafrom-the-rhetoric-of-longinus-to-the-poetics-of-john-dennis/ (last accessed: $01.10 .2018)$

Cora, Zoltán. 2016. "Alexander Pope and the Longinian Tradition of the Sublime." Eger Journal of English Studies, 16: 5-25.

Fairer, David. 1989. The Poetry of Alexander Pope. London: Penguin.

Hollander, John and Frank Kermode. 1973. eds. The Oxford Anthology of English Literature. Vol. III. The Restoration and the Eighteenth Century. New York London: Oxford University Press.

Johnson, Samuel. 1975. "Joseph Addison, Periodical Essays." Lives of The English Poets. Ed. John Wain. London: J. M. Dent, 200-205.

Kant, Immanuel. 2000. Critique of the Power of Judgment. 1790. Trans. Paul Guyer and Eric Matthews. Cambridge: Cambridge University Press. https://doi. org/10.1017/CBO9780511804656

Longinus. 1991. On Great Writing. Ed. and trans. George M. A. Grube. Indianapolis: Hackett.

Lovejoy, Arthur O. 1960. "Nature as Aesthetic Norm." In: Arthur O. Lovejoy, ed. Essays in the History of Ideas. New York: Capricorn, 69-77.

Monk, Samuel Holt. 1960. The Sublime: A Study of Critical Theories in XVIIICentury England. Ann Arbor: University of Michigan Press. 
Neill, Elizabeth. 1997. "Hume's Moral Sublime." British Journal of Aesthetics, 37(3): 246-259. https://doi.org/10.1093/bjaesthetics/37.3.246

Panofsky, Erwin. 1998. Idea. Adalékok a régebbi müvészetelmélet fogalomtörténetéhez. Trans. Szántó Tamás. Budapest: Corvina.

Pappas, Nicholas. 2005. “Aristotle.” In: Berys Gaut and Dominic McIver Lopes, eds. The Routledge Companion to Aesthetics. New York: Routledge, 17-27.

Pope, Alexander. 1965. “An Essay on Criticism.” In: John Butt, ed. Alexander Pope's Collected Poems. London: J. M. Dent, 180-215.

Pope, Alexander. 2008. "Peri Bathous: or, Martinus Scriblerus. His Treatise of the Art of Sinking in Poetry." In: Pat Rogers, ed. Alexander Pope. The Major Works. Oxford: Oxford University Press, 195-239, 630-635.

Rogers, Pat. 1975. An Introduction to Pope. London: Methuen.

Rogers, Pat, ed. 2008. Alexander Pope. The Major Works. Oxford: Oxford University Press.

Ross, Angus, ed. 1982. Selections from The Tatler and The Spectator of Steele and Addison. Aylesbury, Penguin Books: Hazell Watson \& Viney.

Sanders, Andrew, ed. 1996. The Short Oxford History of English Literature. Oxford: Clarendon.

Shaftesbury, Third Earl of. 2003. "The moralists, a philosophical rhapsody, being a recital of certain conversations on natural and moral subjects." Characteristics of Men, Manners, Opinions, Times. Ed. Lawrence Klein. Cambridge: Cambridge University Press, 231-338.

Shelley, James. 2005. "Empiricism: Hutcheson and Hume." In: Berys Gaut and Dominic McIver Lopes, eds. The Routledge Companion to Aesthetics. New York: Routledge, 41-54.

Townsend, Dabney. 1992. "Shaftesbury's Aesthetic Theory." The Journal of Aesthetic and Art Criticism, 41(2): 205-213. https://doi.org/10.2307/430270

Wood, Theodore E. B., ed. 1972. The Word 'Sublime' and Its Context (1660-1760). The Hague and Paris: Mouton. 